\title{
Studi Empiris Faktor Determinan Prestasi Kerja Pegawai
}

\author{
Manajemen Sumber Daya Manusia
}

\author{
Rita Safitri $^{1)}$, Heri Purwanto ${ }^{2)}$, M. Trihudiyatmanto ${ }^{3)}$, M. Elfan Kaukab ${ }^{4 *}$ \\ Fakults Ekonomi dan Bisnis, Universitas Sains Al-Qur'an Wonosobo \\ *Email: elvankaukab@yahoo.com
}

\begin{abstract}
Job performance is a result of work in quality and quantity achieved by an employee in carrying out his duties by the responsibilities that have been given to him. An employee is said to be successful in carrying out his job if the work obtained is higher than the predetermined standard. The purpose of this study was to determine and analyze the effect of training, promotion, and transfer on the work performance of the employees of the Social and Village Empowerment Service Office of Wonosobo Regency. This study uses a quantitative approach. The population of this study was all employees of the Social and Village Empowerment Office of Wonosobo Regency. Methods of data analysis using multiple linear regression. The conclusion of this study is (1) partially training has a significant effect on job performance. (2) partially, job promotion has a significant effect on work performance. (3) partially, the mutation has a significant effect on work performance. (4) simultaneous training, promotion, and transfer have a significant effect on work performance.
\end{abstract}

Keywords: Training, job promotion, movements, job performance

\section{PENDAHULUAN}

Era globalisasi ini semakin berkembang pesat membuat suatu organisasi/lembaga pemerintahan dituntut untuk mempertahankan prestasi kerja sumber daya manusianya. Dengan harapan dapat mencapai suatu tujuan yang telah ditetapkan dan sumber daya manusia atas pegawainya dapat bekerja secara efektif, efisen, memiliki prestasi kerja yang baik pula. Peranan sumber daya manusia amatlah penting dan tidak mungkin bisa diabaikan. Justru sumber daya manusialah yang menentukan apakah sebuah tujuan dapat tercapai dengan tepat dan baik.

Menurut Handoko (2014) mengemukakan bahwa sumber daya terpenting suatu organisasi adalah sumber daya manusia, orang-orang yang memberikan tenaga, bakat, kreativitas, dan usaha mereka kepada organisasi. Penanganan sumber daya manusia berbeda dengan berbagai faktor produksi lainnya dikarenakan sumber daya manusia selalu dapat berkembang dan bertambah baik dari segi kuantitas maupun kualitasnya.

Berbagai upaya ditempuh untuk dapat meningkatkan kualitas pegawai agar efektivitas dan efisiensi kerja dapat tercapai, salah satu bentuk upaya untuk dapat meningkatkan kualitas dan rasa tanggung jawab pegawai dalam memberikan pelayananadengan adanya program pengembangan karir yaitu dengan cara melakukan program pelatihan, promosi jabatan, dan mutasi. Penilaian prestasi dapat menyediakan kesempatan, bagi pemimpin dan pegawai untuk bersama-sama meninjau perila$\mathrm{ku}$ yang berkaitan dengan pekerjaan, kare- 
na pada umumnya setiap orang membutuhkan dan meninginginkan umpan balik tentang prestasi kerja mereka. (Dinas \& Kabupaten, 2002)

Dinas Sosial, Pemberdayaan Masyarakat dan Desa (DinsosPmd) Kabupaten Wonosobo merupakan sebuah organisasi/lembaga pemerintahan yang bergerak pada bidang sosial publik. Berdasarkan peraturan Bupati Wonosobo Nomor 41 Tahun 2016, Instansi ini memiliki tugas membantu Bupati dalam melaksanakan urusan pemerintahan bidang sosial dan bidang Pemberdayaan Masyarakat dan Desa yang menjadi kewenangan daerah dan Tugas Pembantu yang ditugaskan kepada daerah.

pelaksanaan evaluasi dan pelaporan di bidang sosial dan pemberdayaan masyarakat dan desa, (5) pelaksanaan pemberdayaan sosial dan penanganan kemiskinan, (6) pelayanan dan rehabilitasi sosial serta pelaksanaan bantuan dan jaminan sosial, (7) pemberdayaaan lembaga kemasyarakatan dan lembaga adat tingkat Desa, (8) pelaksanaan fungsi kesekertariatan dinas, (9) pengendalian penyelenggaraan tugas unit pelaksanaan teknis, dan (10) pelaksana fungsi lain yang diberikan oleh Bupati terkait dengan tugas dan fungsinya.

Dari hasil pengamatan yang dilakukan, bahwa prestasi kerja Dinas Sosial, pemberdayaan Masyarakat dan Desa (DinsosPmd) Kabupaten Wonosobo mengalami penurunan. Hal ini dapat dilihat pada $\mathrm{Re}$ kapitulasi Nilai Prestasi Kerja Pegawai (NPKP) Kantor Dinas Sosial, Pemberdayaan Masyarakat dan Desa Kabupaten Wonosobo selama dua tahun terakhir (20182019), prestasi kerja cenderung mengalami penurunan sebagaimana yang terlihat dalam tabel sebagai berikut:

Tabel 1. Rekapitulasi Nilai Pestasi Kerja Pegawai (NPKP) Kantor Dinas Sosial, Pemberdayaan Masyarakat, dan Desa Wonosobo

Tahun 2018-2019

\begin{tabular}{|l|c|c|c|c|}
\hline \multirow{2}{*}{ NPKP } & \multicolumn{2}{c|}{ Tahun 2018 } & \multicolumn{2}{c|}{ Tahun 2019 } \\
\cline { 2 - 5 } & Jumlah & Persentase & Jumlah & Persentase \\
\hline Sangat Baik & 14 & 42,42 & 12 & 36,37 \\
\hline Baik & 16 & 48,49 & 15 & 45,45 \\
\hline Cukup & 2 & 6,06 & 4 & 12,12 \\
\hline Kurang & 1 & 3,03 & 2 & 6,06 \\
\hline Buruk & 0 & 0 & 0 & 0 \\
\hline Jumlah Pegawai & 33 & 100 & 33 & 100 \\
\hline
\end{tabular}

Berdasarkan Tabel 1 menjelaskan bahwa terjadi penurunan prestasi kerja dari tahun 2018 ke tahun 2019. Hal tersebut dapat dilihat dari hasil prestasi kerja pegawai NPKP "Sangat Baik" menurun dari tahun 2018 ke tahun 2019 dengan selisih sebesar 6,05 \%. Pada NPKP "Baik" selisih antara tahun 2018 dan 2019 sebesar 3,04 \%. Pada NPKP "Cukup" selisih antara tahun 2018 dan 2019 sebesar -6,06 \%, dalam hal ini dapat diartikan bahwa pegawai mengalami penurunan prestasi yang tinggi, dan pada NPKP "Kurang" selisih antara tahun 2018 dan 2019 sebesar -3,03, dalam hal ini artinya, bahwa pegawai mengalami penurunan prestasi.

Agar dapat mencapai prestasi kerja yang tinggi pemimpin harus memperhatikan segala hal yang berkaitan dengan peningkatan prestasi kerja yang tentunya untuk menunjang peksanaan kerja yang lebih baik. Faktor yang mendukung peningkatan prestasi kerja yaitu pemberian program pelatihan dalam instansi atau organisasi bisa menambah kemampuan dan keahlian didalam menjalankan pekerjaannyan. Prestasi 
kerja yang baik tentunya akan lebih mendekatkan pegawai dengan promosi, menjadi motivasi bagi setiap individu pegawai. Sedangkan pemberian mutasi yang baik dapat menempatkan pegawai pada tempat yang dirasa tepat dan dapat menghilangkan kejenuhan pegawai, hal ini tentunya dapat meningkatkan prestasi kerja pegawai pada instansi atau organisasi tersebut.

\section{TEORI DAN HIPOTESIS}

Dalam pemberian program pelatihan yang efektif akan dapat memperbaiki sikap kerja pegawai menjadi terampil, ahli dan mampu melaksanakan tanggung jawabnya dengan semakin baik dan melalui pelatihan diharapkan dapat memberikan kesempatan untuk meningkatkan karir karyawan semakin besar. Karena keahlian, keterampilan dan prestasi kerja pegawai yang lebih baik menjadi bahan pertimbangan suatu organisasi/lembaga dalam memberikan promosi jabatan. Melalui program-program pelatihan dan pengembangan dirangsang untuk dapat meningkatkan prestasi kerja, mengurangi absensi, dan perputaran.serta memperbaiki kepuasan kerja agar pegawai mampu mendapatkan posisi jabatan yang diinginkan (Handoko, 2002). Beberapa penelitian yang telah dilakukan, ditemukan adanya hubungan yang positif antara pelatihan dan prestasi kerja. Penelitian yang dilakukan Fikri Hidayat (2015), hasil penelitian menyatakan terdapat pengaruh positif antara pelatihan terhadap prestasi kerja pegawai. Selanjutnya penelitian yang dilakukan Rizqi Dwi Utami (2017), juga mengatakan bahwa pelatihan kerja berpengaruh signifikan terhadap prestasi kerja. Hal ini berarti bahwa pelatihan kerja meningkat, maka akan meningkatkan prestasi kerja. Berdasarkan uraian di atas maka dapat merumuskan hipotesis sebagai berikut :

$\mathrm{H}_{1}$ : Pelatihan berpengaruh positif terhadap prestasi kerja pegawai

Promosi yang dilaksanakan harus berdasarkan penilaian kejujuran, kemampuan, serta kecakapan yang dimiliki pega- wai dalam melaksanakan pekerjaan. Promosi pun harus dilakukan dengan jujur dan objektif serta tidak pilih kasih. Setiap pegawai yang dianggap memiliki prestasi kerja yang tinggi harus diprioritaskan untuk dapat dipromosikan, hal tersebut dapat mendorong para pegawai yang lain untuk dapat meningkatkan prestasi kerjanya agar mendapatkan promosi yang diinginkannya. Hal ini sesuai dengan pendapat Hasibuan (2005) mengemukakna bahwa jika ada kesempatan bagi pegawai dipromosikan berdasarkan azas keadilan dan objektivitas, karyawan akan terdorong dapat bekerja lebih giat, bersemangat, disiplin, dan mampu berprestasi kerja sehingga sasaran suatu perusahaan dapat secara optimal dapat tercapai. Penelitian yang telah dilakukan Siti Nurjum'ah (2017), Judas (2013), Septiani (2015), Lumangkun, C.A (2018) menunjukan bahwa Promosi jabatan berpengaruh positif dan signifikan terhadap prestasi kerja pegawai. Dari hasil penelitian tersebut dapat disimpulkan bahawa dengan adanya promosi jabatan yang diberikan instansi akan semakin meningkatkan prestasi kerja pegawai agar mampu memberikan kontribusi lebih kepada instansi. Berdasarkan uraian di atas maka dapat merumuskan hipotesis sebagai berikut:

$\mathrm{H}_{2}$ : Promosi jabatan berpengaruh positif terhadap prestasi kerja pegawai

Menurut Wahyudi (2002), mutasi jabatan akan dapat membuka peluang kesempatan terjadinya persaingan dalam meningkatkan prestasi kerja. Setiap anggota organisasi mempunyai kesempatan yang sama untuk dapat meraih suatu posisi/jabatan/pekerjaan yang dirasa lebih tinggi. Namun perlu diperhatikan bahwa dalam persaingan untuk meningkatkan prestasi kerja akan timbul apabila ada jaminan bahwa mutasi benar-benar dilakukan secara objektif. Dari uraian di atas maka dapat diketahui bahwa pelatihan, promosi, dan mutasi akan mempengaruhi prestasi kerja dalam suatu organisasi/lembaga. Terdapat hubungan positif antara mutasi dengan 
prestasi kerja telah dibuktikan dengan adanya beberapa penelitian Fikri Hidayat (2015), Widianti Nurwaliyah (2014), F.H.Okto (2008) dan Siti Nurjum'ah (2017), pengertian mutasi adalah kegiatan dari pimpinan suatu instansi atau organisasi untuk memindahkan pegawai dari suatu pekerjaan keperkerjaan lain yang dianggap setingkat atau sejajar. Dari pengertian diatas dapat diartikan bahwa mutasi merupakan bentuk dari perubahan perpindahan kerja/jabatan lain dengan harapan pada jabatan baru seorang pegawai akan jauh lebih berkembang. Berdasarkan uraian di atas maka dapat merumuskan hipotesis sebagai berikut :

$\mathrm{H}_{3}$ : Mutasi berpengaruh positif terhadap prestasi kerja pegawai

\section{METODOLOGI}

Populasi dalam penelitian ini adalah seluruh pegawai Kantor Dinsos Pmd Kabupaten Wonosobo sebanyak 33 pegawai. Teknik pengambilan sampel dilakukan dengan cara total sampling atau juga disebut dengan sampel sensus, adalah teknik sampling yang dilakukan dengan mengambil seluruh populasi (Sugiyono, 2018). Menggunakan teknik sampling jenuh karena sampel kecil kurang dari 100 sehingga penelitiannya merupakan penelitian populasi.

Definisi operasional variabel diukur dengan indicator yang telah disusun. Menurut Mangkunegara (2011) indikator sumber daya manusia dalam prestasi kerja pegawai yaitu: kualitas kerja, kuantitas kerja, kerja sama, tanggungjawab, inisiatif dan disiplin. Indicator pelatihan menurut Mangkunegara (2011) adalah Instruktur, peserta, materi, metode dan sarana. Indikator variabel promosi jawabatan menurut Hasibuan (2014) adalah masa kerja, memenuhi standar promosi, peningkatan karier, kecakapan, ketelitian dan keadilan. Indikator variabel mutasi menurut Hasibuan (2014) yaitu waktu mutasi, banyaknya mutasi, kemampuan kerja, kedisiplinan, keje- lasan informasi pelaksanaan mutasi dan evaluasi penelitian.

Teknik analisis data menggunakan regresi linear berganda dengan langkah menganalisis statistik deskriptif kemudian menguji ketepatan model (Uji F). Sebelum menganalisis hipotesis dilakukan uji kualitas data dengan mengukur validitas dan reliabilitas. Kemudian dilakukan pengujian asumsi klasik berupa uji normalitas, multikolonieritas, dan heterokedastisitas. Terakhir uji determinasi $\left(\mathrm{R}^{2}\right)$ dilakukan untuk mengetahui besar keterikatan atau keeratan variabel dependen.

\section{HASIL DAN PEMBAHASAN}

\section{Hasil}

Hasil uji validitas menyatakan bahwa variabel pelatihan $\left(\mathrm{X}_{1}\right)$, promosi jaba$\tan \left(\mathrm{X}_{2}\right)$, dengan menampilkan seluruh item pernyataan yang bersangkutan dari faktor Pelatihan, hasil yang didapatkan yaitu keseluruhan nilai signifikasi lebih kecil dari alpha $(0,05)$, dan nilai $\mathrm{R}_{\text {hitung }}$ lebih besar dari $\mathrm{R}_{\text {tabel }}(0,344)$. Dengan demikian seluruh item pernyataan dinyatakan valid.

Hasil uji validitas menyatakan bahwa variabel promosi jabatan $\left(\mathrm{X}_{2}\right)$ dan mutasi $\left(\mathrm{X}_{3}\right)$ dengan menampilkan seluruh item pernyataan yang bersangkutan, hasil yang didapatkan yaitu keseluruhan nilai signifikasi lebih kecil dari alpha $(0,05)$, dan nilai $R_{\text {hitung }}$ lebih besar dari $R_{\text {tabel }}$ $(0,344)$. Dengan demikian seluruh item pernyataan dinyatakan valid.

Hasil uji realibilitas dengan nilai cronbach's alpha pada variabel Pelatihan dengan nilai 0,714 , variabel Promosi Jaba$\tan 0,849$, Mutasi 0,767, dan variabel Prestasi Kerja dengan nilai 0,736, maka dapat dinyatakan bahwa semua variabel memiliki reliabilitas.

Menurut Suliyanto (2011) uji Goodness of Fit atau uji ketepatan model merupakan uji yang bertujuan untuk menentukan apakah spesifikasi model yang ditetapkan sudah tepat atau tidak. Uji ini juga merupakan uji pengaruh secara simultan 
variabel independen dan dependen. Hasil uji $\mathrm{F}$ diperoleh F-hitung sebesar 51,007 dan sing 0,000. F-tabel pada $\alpha=0,05$, df1 $=($ jumlah variabel independen $=3$ ) dan df2 (n-k-1 = 33-3-1 = 29), maka nilai Ftabel $=2,93$. Hal ini berarti F-hitung $>$ Ftabel $(51,007>2,93)$ dan sig $<0,05(0,000$ $<0,05)$, maka hipotesis dapat diterima. Dalam hal ini dapat dikatakan bahwa variabel pelatihan, promosi jabatan dan mutasi secara bersama-sama berpengaruh nyata terhadap prestasi kerja, sehingga ketiga variabel independen tersebut dapat digunakan untuk mengestimasi atau memprediksi variabel prestasi kerja.

Hasil uji asumsi klasik dilihat dari beberapa uji. Pertama uji normalitas, nilai Asymp.sig (2-tailed) Kolmogorov-Smirnov adalah 0,200 lebih besar dari 0,05. Hal tersebut menunjukkan bahwa variabel tersebut berdistribusi normal. Uji multikolinieritas, nilai tolerance variabel Pelatihan $0,643>0,1$, Promosi Jabatan 0,682 > 0,1, dan Mutasi 0,609>0,1 dan nilai VIF variabel Pelatihan 1,554 < 10, Promosi Jabatan 1,466 < 10 dan Mutasi 1,642 < 10 artinya tidak ada gejala Multikolinearitas atau hubungan di antara ketiga variabel bebas tersebut. Uji heteroskedastisitas, grafik scatterplot diketahui titik menyebar diatas dan di bawah 0 pada sumbu Y. Maka dapat disimpulkan bahwa model regresi yang digunakan tidak terjadi heteroskedastisitas.

Hasil dari pengujian hipotesis dapat dilihat pada tabel 2 sebagai berikut:

Tabel 2. Hasil Uji Hipotesis

\begin{tabular}{|c|c|c|c|c|c|}
\hline \multirow[b]{2}{*}{ Model } & \multicolumn{2}{|c|}{$\begin{array}{l}\text { Unstandardized } \\
\text { Coefficients }\end{array}$} & \multirow{2}{*}{$\begin{array}{c}\text { Standardized } \\
\text { Coefficients } \\
\text { Beta }\end{array}$} & \multirow[t]{2}{*}{$\mathrm{t}$} & \multirow[t]{2}{*}{ Sig. } \\
\hline & $B$ & Std. Error & & & \\
\hline 1 (Constant) & 2,389 & 1,816 & & 1,316 & 199 \\
\hline Pelatihan & 200 & ,091 & 202 & 2,182 & 037 \\
\hline Promosi Jabatan &, 550 & ,075 & ,655 & 7,303 & ,000 \\
\hline Mutasi & , 188 & ,081 & ,219 & 2,306 & ,028 \\
\hline
\end{tabular}

$\mathrm{Y}=2,389+0,200 \mathrm{X}_{1}+0,550 \mathrm{X}_{2}+0,188 \mathrm{X}_{3}$ $+\mathrm{e}$

Dari persamaan regresi diatas dapat diketahui bahwa:

1. Nilai $(\alpha)$ konstanta sebesar 2,389 (positif) hal ini menunjukan bahwa dengan dipengaruhi oleh variabel independen, yaitu pelatihan, promosi jabatan dan mutasi, maka para pegawai memiliki tingkat kinerja yang baik, sehingga prestasi kerja pegawai meningkat.

2. Besarnya pelatihan berbanding lurus dengan prestasi kerja dengan koefisien 0,200 dengan tingkat signifikan pada 0,037, karena memiliki tingkat signifikan kurang dari 0,05 maka H1 yang menyatakan bahwa terdapat pengaruh positif antara pelatihan terhadap prestasi kerja diterima. Artinya bahwa pemberian pelatihan untuk para pegawai pada DinsosPmd akan dapat menimbulkan perubahan dalam kebiasaan kerja, peru- bahan sikap, tingkah laku, keterampilan serta pengetahuan pegawai yang jauh lebih baik dan dengan hal tersebut akan meningkatkan prestasi kerja pada kantor DinsosPmd.

3. Promosi jabatan berbanding lurus dengan prestasi kerja dengan koefisien 0,550 dengan tingkat signifikan pada 0,000 , karena memiliki tingkat singnifikan kurang dari 0,05 maka $\mathrm{H} 2$ yang menyatakan bahwa terdapat pengaruh positif antara promosi jabatan terhadap prestasi kerja diterima. Artinya bahwa promosi yang dilakukan dapat membentuk perilaku pegawai terhadap pekerjaan yang bisa meningkatkan semangat kerja pegawai dengan baik.

4. Mutasi berbanding terbalik dengan prestasi kerja pegawai dengan koefisien 0,188 dengan tingkat signifikan pada 0,028 , karena memiliki tingkat signifikan kurang dari 0,05 maka $\mathrm{H} 3$ yang 
menyatakan bahwa terdapat pengaruh positif antara mutasi terhadap prestasi kerja. Artinya bahwa mutasi yang diberikan pada kantor DinsosPmd dengan harapan pegawai yang dipindahkan pada posisi baru, akan lebih dapat berkembang dalam kariernya dan tentu hal tersebut kan meningkatkan prestasi kerjanya.
Determinasi $\left(\mathrm{R}^{2}\right)$ pada intinya mengukur proprosi atau presentase sumbangan variabel bebas yaitu variabel independen pelatihan, promosi jabatan dan mutasi terhadap variasi naik turunya variabel terikat prestasi kerja secara bersama-sama, dimana : $0 \leq \mathrm{R}^{2} \leq 1$

Tabel 3. Hasil Uji Determinasi $\left(\mathbf{R}^{2}\right)$

\begin{tabular}{|l|c|r|r|r|}
\hline Model & $\mathrm{R}$ & $\mathrm{R}$ Square & $\begin{array}{r}\text { Adjusted } \\
\text { R Square }\end{array}$ & Std. Error of the Estimate \\
\hline 1 &, $917^{\mathrm{a}}$ &, 841 &, 824 & 1,248 \\
\hline
\end{tabular}

Berdasarkan Tabel 3, dapat dilihat bahwa besarnya nilai adjusted $\mathrm{R}^{2}$ adalah 0,841 yang berarti besar pengaruh pelatihan, promosi jabatan dan mutasi terhadap prestasi kerja sebesar $84,1 \%$ sedangkan sisannya $15,9 \%(100 \%$ - 84,1 \%) dijelaskan oleh variabel bebas lainnya. Hal ini menunjukan bahwa masih ada faktorfaktor lain di luar faktor pelatihan, promosi jabatan dan mutasi.

\section{Pembahasan}

Hasil penelitian ini menunjukkan bahwa Pelatihan berpengaruh positif terhadap prestasi kerja sehingga $\mathrm{H} 1$ diterima. Artinya dengan pemberian pelatihan akan dapat menimbulkan perubahan dalam kebiasaan kerja, perubahan sikap, tingkah laku, keterampilan serta pengetahuan pegawai, pelatihan harus dilakukan secara terus menerus agar dapat menyesuaikan dengan perkembangan ilmu pengetahuan saat ini. Pelatihan menjadi faktor penting dalam mempengaruhi prestasi kerja. Hal tersebut dukung oleh penelitian Siti Nur'jumah (2017) bahwa pelatihan secara langsung mempengaruhi prestasi kerja pegawai dalam melakukan pekerjaannya. Pemberian pelatihan akan dapat menimbulkan perubahan dalam kebiasaan kerja, perubahan sikap, tingkah laku, keterampilan serta pengetahuan pegawai yang dapat meningkatkan prestasi kerja, maka semakin sering di lakukan pelatihan akan dapat meningkatkan prestasi kerja dan seba- liknya dengan sedikit diberikan pelatihan maka terdapat kecenderungan semakin rendah prestasi kerja pegawai. Penelitian yang dilakukan Rizqi Dwi Utami (2017) menyatakan bahwa penelitian berpengaruh positif terhadap prestasi kerja, hasil penelitian juga sesuai dengan penelitian Muhammad Indrawan (2015), dan Alika Rachma Putri 2018 menyatakan bahwa pelatihan berpengaruh positif terhadap prestasi kerja. Pelatihan merupakan suatu proses belajar untuk memperoleh dan meningkatkan keterampilan diluar sistem pendidikan yang berlaku dalam waktu relatif singkat dengan berbagai metode. Untuk dapat menjalankan program pelatihan pada Kantor DinsosPmd dibutuhkan suatu perencanaan yang baik, sistematis dan terarah sehingga dapat memberikan masukan positif bagi organisasi/lembaga. Biaya dalam melakukan pelatihan cukup besar, maka pelatihan kerja pegawai harus berasil dan berpengaruh positif terhadap prestasi kerjanya.

Hasil penelitian ini menunjukkan bahwa Promosi Jabatan berpengaruh positif terhadap prestasi kerja sehingga $\mathrm{H} 2$ diterima. Artinya, setiap pegawai yang mempunyai keinginan mengalami kenaikan jabatan yang tinggi akan cenderung memiliki kinerja yang tinggi dengan melalui promosi jabatan dapat membentuk perilaku pegawai untuk bisa meningkatkan semangat kerja dengan baik. Hal ini sejalan dengan penelitian Lumangkun, C.A (2018), Sabar, N.D (2017) dan Nurdin 
(2015) menyatakan bahwa Promosi jabatan berpengaruh positif dan sigifikan terhadap Prestasi kerja. Hal ini berarti variabel promosi jabatan merupkan salah satu variabel yang dapat mempengaruhi prestasi kerja. Promosi jabatan adalah perubahan posisi/jabatan atau pekerjaan dari tingkat rendah ke yang lebih tinggi, biasanya akan diikuti dengan meningkatnya tanggungjawab, hak, serta status sosial seseorang. Dengan adanya promosi jabatan yang diberikan organisasi/lembaga akan dapat membentuk perilaku pegawai terhadap pekerjaan yang tentunya hal tersebut bisa meningkatkan semangat kerja pegawai dengan baik. Terdapat hubungan positif antara promosi jabatan dan prestasi kerja, oleh karena itu promosi jabatan menjadi faktor penting dalam mempengaruhi prestasi kerja. Dengan melakukan promosi jabatan pada Kantor DinsosPmd akan memberikan kesempatan kepada para pegawai untuk dapat mengembangkan kreativitas dan inovasi yang lebih baik demi keuntungan organisasi/lembaga. Kesempatan promosi jabatan yang diberikan kepada pihak pegawai akan tercipta suatu keinginan dari pegawai untuk memotivasi dirinya sendiri dalam meningkatkan prestasi kerjanya.

Mutasi berpengaruh positif terhadap prestasi kerja sehingga $\mathrm{H} 3$ pada penelitian ini diterima. Artinya, bahwa pemberian mutasi yang baik akan menempatkan pegawai pada tempat yang tepat dan menghilangkan kejenuhan pegawai yang akan dapat meningkatkan prestasi kerja pegawai. Hasil penelitian ini sejalan dengan penelitian oleh Husaini Abdullah (2018) dengan hasil penelitian pengaruh positif terhadap prestasi kerja. Hasil penelitian juga sejalan dengan penelitian Judas (2013), Fathiyah, Bahrina Liapijannah (2016), dan Abdullah Zailani (2015) menunjukkan bahwa mutasi berpengaruh positif terhadap prestasi kerja. Mutasi adalah suatu perubahan posisi jabatan atau pekerjaan yang dilakukan secara horizontal didalam suatu organisasi. Mutasi termasuk bentuk pengembangan karir pegawai karena bertujuan untuk dapat meningkatkan efisiensi dan efektifitas kerja pegawai dalam organisasi/lembaga sehingga pegawai dapat menempati posisi jabatan baru, memperoleh suasana baru dan kepuasan kerja, hal tersebut dapat meningkatkan prestasi kerja. Pemberian Mutasi pada Kantor DinsosPmd Kabupaten Wonosobo diharapkan pegawai tidak merasa bosan terhadap suasana kerjanya ataupun agar pegawai lebih berkembang dalam kariernya karena berada pada tempat yang tepat. Mutasi merupakan salah satu tindak lanjut yang dilakukan dari hasil penilaian prestasi pegawai, mutasi harus didasarkan pada indeks prestasi yang dapat dicapai oleh pegawai yang bersangkutan. Namun selain hal tersebut mutasi dilakukan karena berbagai macam alasan seperti keinginan sendiri, penurunan prestasi kerja, mengisi kekosongan posisi dan alih tugas produktif. Mutasi tidak terlepas dari alasan untuk dapat mengurangi rasa bosan pegawai kepada pekerjaanya serta meningkatkan motivasi dan semangat kerja pegawai, selain itu untuk dapat memenuhi keinginan pegawai sesuai dengan minat dan bidang masing-masing.

\section{KESIMPULAN}

Berdasarkan pada data yang telah dikumpulkan dan hasil pengujian yang telah dilakukan terhadap permasalahan dengan menggunakan regresi linier berganda, maka dapat disimpulkan sebagai berikut pelatihan berpengaruh positif terhadap prestasi kerja (H1 diterima). Artinya, semakin baik perencanaan, sistematis dan terarah dalam pelatihan akan dapat meningkatkan prestasi kerja. Promosi Jabatan berpengaruh positif terhadap prestasi kerja ( $\mathrm{H} 2$ diterima). Artinya, semakin baik pemberian promosi jabatan, pegawai akan terdorong bekerja giat, bersemangat, berdisiplin dalam meningkatkan prestasi kerja. Mutasi berpengaruh positif terhadap prestasi kerja (H3 diterima). Artinya, semakin sering diadakan mutasi akan meningkatkan 
prestasi kerja karena bekerja pada tempat yang tepat.

Setelah mengetahui hasil dari penelitian ini, ada beberapa saran yang dapat direkomendasikan hendaknya semua pegawai dalam meningkatkan prestasi kerjanya lebih bisa memfokuskan pada pelatihan, promosi jabatan dan mutasi. Dengan memperoleh pelatihan yang lebih baik pegawai mampu meningkatkan prestasi kerja yang tentunya hal tersebut dapat meningkatkan dan menghasilkan output yang jauh lebih baik lagi yang dapat menguntungkan bagi kantor DinsosPmd. Memberikan motivasi kepada para pegawai untuk menjadi lebih baik dengan memberikan jaminan ketersediaan promosi jabatan terhadap prestasi kerja pegawai yang berprestasi. Dengan pemberian mutasi yang diharapkan dapat menjamin keadilan dan kesesuaian penempatan seseorang pegawai pada suatu jabatan agar dapat mendorong berkembangnya kemampuan pegawai dalam meningkatkan prestasi kerja yang lebih baik. Untuk penelitian selanjutnya diharapkan dalam pengambilan sampel lebih luas lagi dan bisa menambah variabel independen agar dapat melengkapi penelitian ini dan memperluas pembahasan sehingga menghasilkan penelitian yang lebih baik.

\section{DAFTAR PUSTAKA}

Abdullah, H. (2018). Pengaruh Promosi Dan Mutasi Jabatan Terhadap Prestasi Kerja Pegawai Pada Pengadilan Negeri Sigli.Jurnal Sosial Humaniora Sigli.

Aini, N., \& Tulus, T. (2015). Analisis Pengaruh Rotasi dan Mutasi Kerja Terhadap Kinerja Karyawan di KJKS BMT Anda Salatiga. Muqtasid: Jurnal Ekonomi dan Perbankan Syariah.

Amalia, M. R. (2018). Analisis Pengaruh Pelatihan, Bantuan Modal, dan Cara Pengelolaan Usaha Terhadap Pendapatan Usaha Mikro Kecil dan
Menengah .Permana : Jurnal Perpajakan, Manajemen, Dan Akuntansi, 10(2), 248-256. https://doi.org/10.24905/permana.v10 i2. 85

Asikin, Pangki Yonathan. 2012. Pengaruh Pelatihan Terhadap Prestasi Kerja Karyawan pada Divisi Sumber Daya Manusia PT. Industri Telekomunikasi

Baharuddin, S. M., \& Syachbrani, W. (2019). Analisis Pengaruh Pelatihan dan Promosi terhadap Prestasi Kerja Pada Dinas Pertanian dan Perternakan Kabupaten Pinrang. Bongaya Journal for Research in Management (BJRM).

Cabang, P., \& Yani, A. (2015). Jurnal ilmiah "INTEGRITAS" Vol.1 No. 3 Oktober 2015.

Dessler, Garry. 2014. Manajemen Sumber Daya Manusia. Jakarta : PT. Gramedia Pustaka Utara.

Dinas, P., \& Kabupaten, P. (2002). Sosial Humaniora vol I No. II | 109 Sosial Humaniora vol I No . II | 110. I

Hidayat, F. (2015). Pengaruh Pelatihan, Promosi Jabatan Dan Mutasi Terhadap Prestasi Kerja Karyawan Pada Direktorat Personalia Dan Umum Pt. Pelabuhan Indonesia I (Persero) Medan.

Handoko, T. Hani. 2012. Manajemen. Yogyakarta : BPFE Yogyakarta

Hariandja, Marihot T.E. 2009. Manajemen Sumber Daya Manusia. Jakarta : Grasindo

Hasibuan, Malayu, S.P.2014. Manajemen Sumber Daya Manusia. Jakarta : Bumi Aksara.

Indrawan, M. I., \& SE, M. (2015). Pengaruh Promosi Jabatan dan Mutasi terhadap Prestasi Kerja Pegawai PT. Bank Mandiri (Persero) Cabang 
Ahmad Yani

Indonesia (INTI) Persero Bandung. Skripsi. Universitas Widyatama.

Judas, A. (2013). Mutasi Dan Promosi Jabatan Pengaruhnya Terhadap Prestasi Kerja Pegawai Pada Kanwil Ditjen Kekayaan Negara Suluttenggo Dan Maluku Utara Di Manado. Jurnal Riset Ekonomi, Manajemen, Bisnis Dan Akuntansi.

Kurniawan, M. (2018). Faktor-Faktor Yang Mempengaruhi Prestasi Kerja Karyawan Pada PT. Excelcomindo Engineering IndonesiaSumatera Muhammad Kurniawan.

Lumangkun, C. A., Mangantar, M., \& Uhing, Y. (2018). Analisis Pengaruh Pelatihan, Promosi dan Mutasi Pegawai pada Dinas Pangan Provinsi Sulawesi Utara. Jurnal EMBA: Jurnal Riset Ekonomi, Manajemen, Bisnis dan Akuntansi.

Mangkunegara, Anwar Prabu. 2011. Manajemen Sumber Daya Manusia Presusahaan. Bandung : PT. Remaja Rosda Karya.

Mukti, H. (2012). Analisis Faktor-faktor yang mempengaruhi Prestasi Kerja Pegawai Pada Kantor Camat Kecamatan Pasir Limau Kapas Kabupaten Rokan Hilir(Doctoral dissertation, Universitas Islam Negeri Sultan Syarif Kasim Riau).

Nur'jumah, S. I. T. I. (2017). Pengaruh Pelathan, Promosi Jabatandan Mutasi terhadap Prestasi Kerja Pegawai Kantor Wilayah Direktorat Jenderal Pajak (DJP) Bengkulu dan Lampung. (Doctoral dissertation, IBI DARMAJAYA).

Novika, P. W. (2018). Pengaruh Mutasi dan Pelatihan Kerja terhadap Semangat Kerja dan Dampaknya pada
Prestasi Kerja Pegawai pada Kantor Kementerian Agama Kota Cilegon. Journal of Economic, Bussines and Accounting (COSTING).

Okto, F. H. (2008). Analisis Pengaruh Pelatihan, Promosi dan Mutasi Pegawai terhadap Prestasi kerja Kepala Sekolah Dasar di Kecamatan Kebakkramat (Doctoral dissertation, Universitas Muhammadiyah Surakarta).

Putri, A. R. (2018). Pengaruh pendidikan dan pelatihan serta promosi jabatan terhadap prestasi kerja pegawai (studi kasus pada bapertarumpns) (Bachelor's thesis, Jakarta: Fakultas Ekonomi dan Bisnis UIN Syarif Hidayatullah Jakarta).

Rustandi, B. M., \& Merdiana, C. V. (2020). Analisiss Pengaruh Promosi Jabatan, Mutasi, dan Pelatihan terhadap Pengembangan Karir Karyawan Distrik Navigasi Kelas III Cilacap. Jurnal Fokus Manajemen Bisnis.

Sabar, N. D., Adolfina, A., \& Dotulong, L. O. (2017). Pengaruh Promosi Jabatan dan Mutasi Terhadap Kinerja Pegawai (Studi pada Pegawai Kantor Wilayah Direktorat Jenderal Perbendaharaan Provinsi Sulawesi Utara).Jurnal EMBA: Jurnal Riset Ekonomi, Manajemen, Bisnis dan Akuntansi.

Sujarweni, V. Wiratna. 2015 Metode Penelitian : Lengkap, Praktis dan Mudah Dipahami. Yogyakarta : Pustaka Baru Press.

Sunyoto, Danang. 2012. Teori Kuesioner dan Analisis Data Sumber Daya Manuisa. Yogyakarta : Penerbit CAPS.

Suparinah, E. (2018). Pengaruh Mutasi dan Promosi Jabatan Terhadap Kinerja Karyawan Pada PT Waru Kaltim 
Plantation Di Penajam Paser Utara.

Surata, I. M., \& Paramarta, W. A. (2017).

Pengaruh Kebijakan Mutasi Dan

Promosi Jabatan Terhadap Kepuasan

Kerja Dan Prestasi Kerja Pegawai

Pada Bagian Administrasi Umum Dan

Keuangan Di Politeknik Negeri

Bali. SOSHUM: Jurnal Sosial dan

Humaniora [Journal of Social

Sciences and Humanities].

Wattimena, S. H. (2017). Pengaruh

Pelatihan dan Promosi Jabatan

terhadap Prestasi Kerja Karyawan

pada PT. Indosat Tbk.

Bandung. Almana: Jurnal Manajemen

dan Bisnis. 